\title{
$\alpha-1-$ Microglobulin: epidemiological indicator for tubular dysfunction induced by cadmium?
}

\author{
Tanja Pless-Mulloli, Michael Boettcher, Markus Steiner, Jürgen Berger
}

Department of Epidemiology and Public Health, School of Health Sciences, University of Newcastle upon Tyne, UK

T Pless-Mulloli

Kramer Laboratory Association, Lauenburger Strasse 67, 21502 Geesthacht, Germany

M Boettcher

NORDIG Institute for Health Research and Prevention, Alte

Kollau Strasse 32A, 22529 Hamburg 54, Germany

M Steiner

Institute of Mathematics and Computer Science in Medicine, University of Hamburg,

Martinistr 52, 20246

Hamburg, Germany

J Berger

Correspondence to: Dr Tanja Pless-Mulloli, Department of Epidemiology and Public Health, School of Health Sciences, University of Newcastle upon Tyne NE2 4HH, UK. Telephone 0044191222 7211; fax 00441912228211 .

Accepted 24 February 1998

\begin{abstract}
Objectives-To evaluate the suitability of

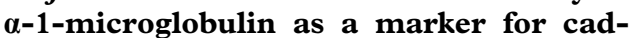
mium induced renal dysfunction.

Methods-a-1-Microglobulin was studied in a cross sectional survey in relation to the body burden of cadmium. Concentrations of $\alpha-1-$ microglobulin in $24 \mathrm{~h}$ urine of 831 people aged $2-87$ years were analysed in association with urinary cadmium excretion, cadmium blood concentration, age, sex, occupational and smoking history, and estimated creatinine clearance. Participants came from a population residentially exposed to cadmium and from two control populations matched for socioeconomic status.

Results-The excretion of $\alpha-1$ microglobulin / $24 \mathrm{~h}$ ranged from $0.1 \mathrm{mg}$ to $176.3 \mathrm{mg}$ and $44.4 \%$ of samples showed concentrations near the detection limit. Ordinal logistic regression analysis of people of all ages identified a high risk only for males compared with females (odds ratio (OR) $2.14 ; 95 \%$ confidence interval $(95 \%$ CI) 1.56 to 2.94), age group, and duration of living on contaminated soil (OR 1.03 I year; $95 \%$ CI 1.02 to 1.04 ), but not urinary cadmium excretion (OR $1.30 ; 95 \%$ CI 0.96 to 1.77) as significant predictors. For people $\leqslant 50$ years of age a weaker effect of sex (OR 1.76; 95\% CI 1.13 to 2.73 ) and age group and an effect of similar magnitude for the duration of soil exposure (OR 1.03; 95\% CI 1.01 to 1.04$)$ were found. Also, the urinary cadmium excretion (OR 2.26; $95 \%$ CI 1.38 to 3.70) and occupational exposure (OR $1.71 ; 95 \%$ CI 1.03 to 2.83 ) were found to be significant in this younger age group. The estimated creatinine clearance had no significant impact on the $\alpha-1-$ microglogulin excretion.

Conclusion- $\alpha-1-$ Microglobulin is a suitable marker for early tubular changes only for people $\leqslant 50$ years. It may not be sufficiently specific for cadmium, and therefore not a suitable surrogate for cadmium exposure in epidemiological studies.

(Occup Environ Med 1998;55:440-445)
\end{abstract}

Keywords: $\alpha-1$-microglobulin; cadmium; marker; renal dysfunction

Cadmium induced renal dysfunction is known to be a threshold process characterised by an increased urinary excretion of proteins once the detoxicating effect of metallothioneine has been exhausted. ${ }^{1-6}$ As long as the glomerular filtration rate exceeds $30 \mathrm{ml} / \mathrm{min}$, low molecu- lar weight proteinuria represents tubular damage. ${ }^{78}$ The three main groups of markers of tubular proteinuria are enzymes, kidney antigens, and low molecular weight proteins. ${ }^{2}{ }^{9-11}$ However, none of the widely available markers of tubular dysfunction have so far been found to be suitable to appropriately characterise renal dysfunction in populations exposed to cadmium. Even though renal effects of environmental exposure to cadmium have been studied in several countries, ${ }^{5-14}$ only a few ${ }^{15-18}$ studied the relation between cadmium and $\alpha$-1-microglobulin.

$\alpha-1-$ Microglobulin is stable in acid urine unlike some other commonly used biomarkers of tubular damage such as $\beta$-2-globulin. Its blood concentrations are relatively stable, being only affected by severe liver disease or renal failure. ${ }^{17}{ }^{19}{ }^{20}$ It has therefore been suggested that the health risk assessment of populations environmentally and occupationally exposed to cadmium could be greatly enhanced if $\alpha-1-$ microglobulin was found to be an appropriate marker for this cadmium effect. ${ }^{19} 20$

The aim of this study was to evaluate the suitability of $\alpha-1$-microglobulin as a marker of cadmium induced renal dysfunction for epidemiological studies.

Data derived from a population based study were used. The body burden and health of people living in a housing estate with soil contaminated with arsenic, heavy metals, and polychlorinated dibenzodioxins and furans (PCDD/F) was compared with two control estates. Medians of heavy metal concentrations in soil from 248 samples were $52.5 \mathrm{mg} / \mathrm{kg}$ for arsenic, $182.0 \mathrm{mg} / \mathrm{kg}$ for lead, $4.2 \mathrm{mg} / \mathrm{kg}$ for cadmium, and $1.8 \mathrm{mg} / \mathrm{kg}$ for mercury. The median PCDD/F concentration from 16 samples was $696 \mathrm{ng} / \mathrm{kg}$ toxicity equivalents (TEQ) ${ }^{21}$ The given exposure situation offered the opportunity to analyse the association between cadmium body burden and $\alpha-1$ microglobulin over a wide range of values of cadmium body burden.

\section{Materials and methods}

STUDY DESIGN AND SAMPLE

The design of the study was cross sectional. During 1992 all residents of a contaminated suburb of Hamburg (Germany) and two control areas with similar socioeconomic status were offered a medical examination including blood and urine testing. In total 1120 people responded to the initial call for participation, providing information about their address, age, sex, and duration of residence in the settlement. Out of these 1033 had their blood 
samples taken, 913 collected urine for 24 hours, and 915 participated in a detailed face to face interview. This was equivalent to a response rate of $80 \%$ in the exposed estate and $35 \%$ and $13 \%$ respectively in the two control groups. ${ }^{21}$ Data on blood and urine samples were complete for 831 people, and for 732 of these, interview data were complete. The descriptive analyses of this paper were based on the number of observations available for each item, the analytical analysis was based on only on the subset for which a complete data set was available.

DATA COLLECTION

The data collection was conducted by the NORDIG Institute of Health Research and Prevention, Hamburg, in a refurbished house within the contaminated housing estate and in a container on a local school ground in the control area. Participating people were given a code number when they came into contact with the study team for the first time. During later visits coded documents were used. Blood and urine samples were collected in cadmium free devices. All laboratories received coded samples and were blinded towards the allocation of individual samples to study or control groups or personal details. Standard urine stix were used to test spot urine at the occasion of the collection of blood samples. Collection devices for the collection of 24 hour urine were handed out when blood samples were collected. These were returned to the study team at varying intervals (days to weeks) after the blood test.

MEASUREMENT OF CADMIUM AND

$\alpha$-1-MICROGLOBULIN

The urinary excretion of cadmium and $\alpha-1$ microglobulin were both measured as the concentration in 24 hour urine. These concentration values can be adjusted by either calculating the excretion / $24 \mathrm{~h}$ or by adjusting for urinary creatinine excretion. Excretion / 24 $\mathrm{h}$ and creatinine adjusted excretion of cadmium and $\alpha-1$-microglobulin had a correlation of 0.93 (Spearman rank correlation) in the data presented here. As the effect of cadmium on urinary creatinine is not well described and more observations were available for the excretion / $24 \mathrm{~h}$, all data are presented as excretion / $24 \mathrm{~h}$.

The cadmium concentration in blood and in 24 hour urine was measured with atomic absorption photometry with a graphite oven at the Institute for Hygiene, Gelsenkirchen, Germany. The detection limit was $0.1 \mu \mathrm{g} / \mathrm{l}$. Quality controls were conducted daily.

The measurement of $\alpha-1$-microglobulin was carried out with LC-Partigen immunodiffusion plates (BEHRING) with polyclonal antiserum against human $\alpha$-1-microglobulin at the Kramer Laboratory Association, Geesthacht, Germany. ${ }^{22}$ The concentration measurement was calculated by firstly reading the diameter of the precipitates. The accuracy of these readings was 0.1 to $0.2 \mathrm{~mm}$. The squares of diameters of the precipitate rings were then used to calculate the concentration of $\alpha$-1-microglobulin against three standard solutions tested simultaneously. ${ }^{22}$ The lowest detectable urinary concentration was described by the manufacturer of the assay as 0.3 $\mathrm{mg} / \mathrm{l}$; for this study a detection limit of $<0.5$ $\mathrm{mg} / \mathrm{l}$ was used. The excretion of $\alpha-1-$ microglobulin / $24 \mathrm{~h}$ was calculated by multiplying the concentration measurements with the volume of urine. For all further statistical analysis values of the excretion of $\alpha-1$ microglobulin $<2.05 \mathrm{mg} / 24 \mathrm{~h}$ were assigned a fixed value of $0.1 \mathrm{mg} / 24 \mathrm{~h}$. The maximum excretion was $2.05 \mathrm{mg} / 24 \mathrm{~h}$ for people with a concentration measurement at the detection limit of $0.5 \mathrm{mg} / 1$.

QUESTIONNAIRE

Interviews were conducted face to face at respondents' homes by trained and supervised interviewers. The questionnaire was designed for the purpose of the study. For this paper certain items from the questionnaire were used: smoking history since 1946, likelihood of occupational exposure to heavy metals since 1946 based on job categories, duration of living on contaminated soil, intake of analgesics and heart medication during the past year, and socioeconomic status.

The smoking history was calculated with pack-years of cigarettes smoked. Non-smoking periods of $<1$ year were considered as noninterrupted smoking. The duration of living on contaminated soil was calculated in years. A value of zero years of residence on contaminated soil was assigned to people from the control groups. The intake of analgesics and heart medication was calculated as the sum of the number of days during the past year with intake of either self purchased or doctor prescribed preparations. The socioeconomic status was calculated with three elements: the highest completed school education, completed professional education, and present profession. The final variable was calculated as the mean of training status and present professional status with a maximum score of $100 .^{21}$ For the analysis of the potential influence of occupational exposure to cadmium, lead, and mercury, 71 professions were classified as having possible occupational exposure. People with at least one working period (out of a maximum of eight) in one of these 71 professions were classified as potentially exposed through their occupation.

\section{STATISTICAL ANALYSIS}

All statistical analysis was performed with the SAS statistical package. ${ }^{23}$ For the analysis of the association between cadmium excretion / $24 \mathrm{~h}$ and $\alpha-1$-microglobulin, ordinal logistic regression was used categorising $\alpha-1-$ microglobulin into five groups. ${ }^{24}$ This was considered the method of choice for the analysis, because of the bimodal frequency distribution of $\alpha-1$-microglobulin in both the exposed and the control groups (figure). Alternatively ordinary logistic regression analysis could have been used. This would have required a normal distribution of residuals, therefore all observations below the detection limit would have to be excluded. Also, it was judged to be inappropriate in a population based study of people of 
Table 1 Distribution of relevant characteristics in the study populations (continuous variables)

\begin{tabular}{|c|c|c|c|c|c|c|c|c|c|}
\hline \multirow[b]{2}{*}{ Continuous variables } & \multicolumn{3}{|c|}{ Exposed group } & \multicolumn{3}{|c|}{ Control groups } & \multicolumn{3}{|c|}{ Total } \\
\hline & $n$ & Median & $I Q R$ & $n$ & Median & $I Q R$ & $n$ & Median & $I Q R$ \\
\hline Age (y) & 574 & 45 & 30 & 257 & 48 & 26 & 831 & 46 & 28 \\
\hline Urine volume collected (ml) & 574 & 1400 & 850 & 257 & 1300 & 800 & 831 & 1400 & 850 \\
\hline Creatinine in urine $(\mathrm{g} / 24 \mathrm{~h})^{\star}$ & 531 & 1.3 & 0.7 & 235 & 1.2 & 0.6 & 766 & 1.3 & 0.7 \\
\hline $\begin{array}{l}\text { Estimated creatinine clearance } \\
(\mathrm{ml} / \mathrm{min}) \dagger\end{array}$ & 512 & 99 & 36 & 235 & 100 & 37 & 747 & 100 & 38 \\
\hline Serum creatinine $(\mathrm{mg} / \mathrm{dl})$ & 571 & 0.9 & 0.2 & 254 & 0.9 & 0.2 & 825 & 0.9 & 0.2 \\
\hline$\alpha-1$-microglobulin $(\mathrm{mg} / \mathrm{l})$ & 574 & 3.0 & 7.7 & 257 & 0.5 & 3.2 & 831 & 1.2 & 6.6 \\
\hline$\alpha$-1-microglobulin $(\mathrm{mg} / 24 \mathrm{~h})$ & 574 & 3.7 & 9.1 & 257 & 1.1 & 3.4 & 831 & 1.6 & 7.4 \\
\hline$\alpha-1$-microglobulin (mg/g creatinine) & 531 & 0.3 & 0.8 & 235 & 0.1 & 0.3 & 766 & 0.2 & 0.7 \\
\hline Cadmium in blood $(\mu \mathrm{g} / \mathrm{l})$ & 567 & 0.7 & 0.8 & 257 & 0.7 & 0.8 & 824 & 0.7 & 0.8 \\
\hline Cadmium in urine $(\mu \mathrm{g} / 24 \mathrm{~h})$ & 574 & 0.39 & 0.42 & 257 & 0.36 & 0.44 & 831 & 0.38 & 0.43 \\
\hline
\end{tabular}

ॠThe creatinine clearance could not be calculated from these data in the standard way, as the serum creatinine concentration was measured at a different time from the collection of 24 hour urine.

†The creatinine clearance was estimated from the concentration of serum creatinine with the formula:

$\underline{0.85 \sim \times \sim(140 \text {-age }) \sim \times \sim \text { body-weight } \sim(\mathrm{kg})}$

$72 \sim \times \sim$ serum $\sim$ creatinine $\sim(\mathrm{mg} / \mathrm{dl})$

for women and the same formula without the factor of 0.85 for men.

$\mathrm{IQR}=$ interquartile range; $\alpha-1-\mathrm{m}=\alpha-1$-microblobulin.

varying ages to define a threshold concentration to dichotomise the data. ${ }^{25}$ The four categories above the detection limit were chosen to include roughly equal numbers of subjects. The categories therefore were: $<2.05$ $\mathrm{mg} / 24 \mathrm{~h}(\mathrm{n}=434), 2.1-5 \mathrm{mg} / 24 \mathrm{~h}(\mathrm{n}=92), 5.1-$ $8.5 \mathrm{mg} / 24 \mathrm{~h}$ ( $\mathrm{n}=104), 8.6-15 \mathrm{mg} / 24 \mathrm{~h}$ $(\mathrm{n}=107)$, and $>15 \mathrm{mg} / 24 \mathrm{~h} \quad(\mathrm{n}=94)$. The resulting odds ratios (ORs) represent a measure of likelihood to cross a given boundary of values of $\alpha-1$-microglobulin in the presence of the predictor with all remaining variables held constant. For linear predictors-such as the excretion of cadmium in the urine-the parameter estimate gives the mean odds per unit increase of the predictor with the remaining variables held constant. The $95 \%$ confidence intervals (95\% CIs) of the OR were calculated with the normal approximation.

\section{Results}

CHARACTERISTICS OF THE SAMPLE

Tables 1 and 2 present the distribution of the relevant characteristics in the total population and the study population stratified by exposure status. The median (range) age of the participants was $46(2-87)$ years. The median age in the exposed group was three years below that of the control groups ( $45 v 48$ ). Forty one participants were children below the age of 14,116 were aged 14-29, 308 were 30-49, 366 were $\geqslant 50$. The people $\geqslant 50$ years old represent a population at high risk of renal dysfunction induced by cadmium.

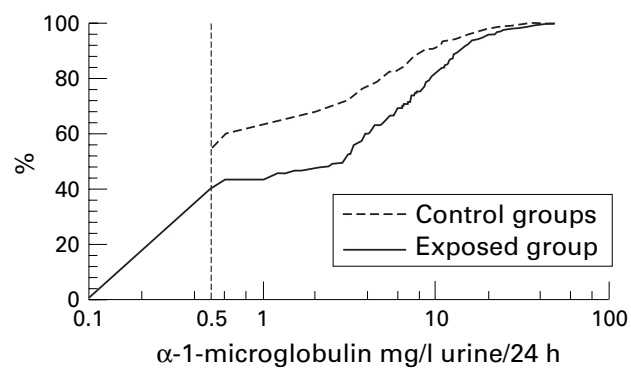

Cumulative frequency distribution of the concentration of a-1-microglobulin in 24 hour urine.
Data on the volume of urine collected, serum creatinine, urine creatinine, the estimated creatinine clearance, and the data on proteins in urine did not suggest any influence of exposure status on the discipline collecting the 24 hour urine sample and therefore the dilution of the urine. The indicators of socioeconomic status confirmed that the two study populations were well matched. However, smoking rates were higher in the exposed group than in the control groups. Only $12 \%$ of spot urine samples showed a positive reaction to indicate traces of protein and only one person had a strongly positive reaction. Even though only a global indicator of glomerular function, this result made it even more unlikely that any variation in glomerular filtration rates could explain variations in $\alpha-1$-microglobulin.

DESCRIPTIVE ANALYSIS OF THE CADMIUM BODY BURDEN AND $\alpha-1$-MICROGLOBULIN

The mean and median (range) cadmium excretion in $24 \mathrm{~h}$ was 0.51 and 0.38 (0.03-3.6) $\mu \mathrm{g}$, and the interquartile range was $0.43 \mu \mathrm{g}$. The median in the exposed group was 0.39 $\mu \mathrm{g} / 24 \mathrm{~h}$ compared with $0.36 \mu \mathrm{g} / 24 \mathrm{~h}$ in the control groups.

The mean and median (range) concentration of $\alpha$-1-microglobulin / $24 \mathrm{~h}$ urine was 4.9 and $1.2(<0.5-146.9) \mathrm{mg} / \mathrm{l} ; 369$ people $(44.4 \%)$ had a concentration of $\alpha-1-$ microglobulin $<0.5 \mathrm{mg} / 1$. The frequency distribution was bimodal for the exposed group as well as for the control groups (figure). The mean and median (range) values of the excretion of $\alpha$-1-microglobulin per $24 \mathrm{~h}$ were 6.3 and $1.6(0.1-176.3) \mathrm{mg} / 24 \mathrm{~h}$. The median for the exposed group was $3.7 \mathrm{mg} / 24 \mathrm{~h}$ compared with $1.1 \mathrm{mg} / 24 \mathrm{~h}$ in the control groups.

Table 3 shows median values, and interquartile ranges of the urinary excretion of $\alpha-1$ microglobulin by the urinary excretion of cadmium/day (5 groups). The median of $\alpha-1$-microglobulin increased with increasing cadmium body burden, reaching a plateau at cadmium excretions of $>0.66 \mu \mathrm{g} / 24 \mathrm{~h}$.

Table 4 presents medians and interquartile ranges per group of $\alpha-1$-microglogulin for 
Table 2 Distribution of relevant characteristics in the study populations (discrete and norminal variables)

\begin{tabular}{|c|c|c|c|c|c|c|}
\hline \multirow[b]{2}{*}{ Discrete and nominal variables } & \multicolumn{2}{|c|}{ Exposed group } & \multicolumn{2}{|c|}{ Control groups } & \multicolumn{2}{|c|}{ Total } \\
\hline & $n$ & $\%$ & $n$ & $\%$ & $n$ & $\%$ \\
\hline Females $(n=831)$ & 297 & 51.7 & 137 & 53.0 & 434 & 52.0 \\
\hline Never smoked $(n=732)$ & 227 & 45.3 & 119 & 51.5 & 346 & 47.3 \\
\hline \multicolumn{7}{|l|}{ Socioeconomic status $(n=731)$ : } \\
\hline Score $0-39$ & 145 & 29.0 & 73 & 31.6 & 218 & 29.8 \\
\hline Score $40-79$ & 312 & 62.4 & 135 & 58.4 & 447 & 61.1 \\
\hline Score $80-100$ & 43 & 8.6 & 23 & 10.0 & 66 & 9.0 \\
\hline Occupational exposure ever $(n=732)$ & 139 & 27.7 & 49 & 21.2 & 188 & 25.7 \\
\hline $\begin{array}{l}\text { Heart medication (yes in past year) } \\
\quad(\mathrm{n}=732)\end{array}$ & 41 & 8.2 & 11 & 4.8 & 52 & 7.1 \\
\hline Analgesics (yes in past year) $(n=732)$ & 96 & 19.2 & 34 & 14.7 & 130 & 17.8 \\
\hline Protein in urine ${ }^{\star}(n=733)$ & 71 & 12.4 & 27 & 10.5 & 98 & 11.8 \\
\hline
\end{tabular}

$\star$ This test used a semiquantitative urine stix test of spot urine. Any positive reaction was recorded.

Table $3 a-1-$ Microglobulin/24 $h$ in association with increasing body burden of cadmium

\begin{tabular}{llll}
\hline \multirow{2}{*}{$\begin{array}{l}\text { Cadmium excretion/ } \\
24 h(\mu g)\end{array}$} & \multicolumn{3}{c}{$a-1-$ Microglobulin/24 $h(\mathrm{mg})$} \\
\cline { 2 - 4 } & $n$ & Median & IQR \\
\hline 0.25 & 266 & 1.1 & 5.5 \\
$0.26-0.45$ & 220 & 1.6 & 6.4 \\
$0.46-0.65$ & 146 & 2.8 & 7.7 \\
$0.66-1.1$ & 125 & 4.5 & 9.9 \\
$>1.1$ & 74 & 4.2 & 11.0 \\
\hline
\end{tabular}

$\mathrm{IQR}=$ interquartile range.

relevant variables. People with higher excretion of $\alpha-1$-microglobulin were found to be older; they had smoked more pack-years of cigarettes, had a lower socioeconomic profile, had lived longer in the contaminated housing estate, and had a higher excretion of cadmium in the urine. There was no clear indication of higher levels of systolic or diastolic blood pressure or of a variation of the intake of analgesics or heart medication by group of excretion of $\alpha-1$ microglobulin. Neither the urine volume collected, the creatinine concentration in serum, the creatinine concentration in urine, or the cadmium concentration in blood varied with the excretion of $\alpha-1$-microglobulin.

One hundred and eighty eight people aged $\geqslant 18$ were identified as having ever had (since 1946) an occupation with likelihood of exposure to cadmium, lead, or mercury. People in the occupationally exposed group were 8.8 years older ( $\mathrm{p}<0.0001)$, had smoked more (10.9 7.0 pack-years, $\mathrm{p}<0.001$ ), had a higher blood pressure (142/89 mm Hg v 136/85 mm $\mathrm{Hg}$; systolic $\mathrm{p}=0.0004$; diastolic $\mathrm{p}<0.0014)$, had a lower socioeconomic status (median score out of $10044.7 v 48.2$, p<0.0059), and had lived longer on contaminated land $(21.6 \mathrm{v}$ 15.1 years, $\mathrm{p}<0.0001)$ than those nonoccupationally exposed. The two groups did differ significantly in their urinary excretion of cadmium / 24 hours (0.57 v $0.49 \mathrm{~g}$; $\mathrm{p}<0.0014)$. The $\alpha$-1-microglobulin excretion was 9.6 $\mathrm{mg} / 24 \mathrm{~h}$ in the exposed group versus $5.0 \mathrm{mg} / 24$ $h$ in the control groups $(p<0.0001)$.

\section{CORRELATION AND REGRESSION}

Spearman rank correlations were calculated to obtain evidence for the inclusion of possible confounders into the regression between cadmium excretion and $\alpha-1$-microglobulin (table 5). Age, the number of packs of cigarettes smoked, the systolic and diastolic blood pressure, the duration of residence on contaminated land, the serum creatinine concentration, and creatinine in urine were significantly associated with both the cadmium excretion and the excretion of $\alpha-1$-microglobulin. They did, therefore, fulfil the preset criteria to be included as confounders. Both the serum and urine creatinine concentrations varied with sex and age, whereas the estimated creatinine clearance allowed for both age and sex in its calculation. Therefore, the estimated creatinine clearance was included in the final model to represent any influence of the glomerular filtration rate on the excretion of $\alpha-1$ microglobulin.

An ordinal logistic regression model was used to analyse the dependency of the $\alpha-1$-microglobulin from explanatory variables (table 6). This was done for the total sample and separately for the age group $\leqslant 50$ years of age. Models were calculated with a complete model including all those variables significantly associated with the excretion / $24 \mathrm{~h}$ of cadmium and $\alpha-1$-microglobulin with the exception of the estimated creatinine clearance. Ordinal

Table 4 Relevant variables/group of a-1-microglobulin

\begin{tabular}{|c|c|c|c|c|c|c|c|c|c|c|c|c|c|c|c|}
\hline & \multicolumn{15}{|c|}{ Excretion of a-1-microglobulin $/ 24 h(m g)$} \\
\hline & \multicolumn{3}{|c|}{$<2.05$} & \multicolumn{3}{|c|}{$2.05-<5$} & \multicolumn{3}{|c|}{$5-<8.5$} & \multicolumn{3}{|c|}{$8.5-15$} & \multicolumn{3}{|c|}{$>15$} \\
\hline & $n$ & Median & $I Q R$ & $n$ & Median & $I Q R$ & $n$ & Median & $I Q R$ & $n$ & Median & $I Q R$ & $n$ & Median & $I Q R$ \\
\hline Age (y) & 434 & 42.5 & 28 & 92 & 44.0 & 30 & 104 & 51.5 & 25 & 107 & 48.0 & 30 & 94 & 57.0 & 22 \\
\hline Pack-years of cigarettes smoked (n) & 382 & 0 & 11 & 82 & 1.77 & 11 & 95 & 1.00 & 12 & 95 & 5.15 & 19 & 78 & 5.19 & 19 \\
\hline $\begin{array}{l}\text { Socioeconomic status (max score } \\
100 \text { ) }\end{array}$ & 381 & 47.0 & 22 & 82 & 46.7 & 27 & 95 & 42.5 & 27 & 95 & 46.0 & 25 & 78 & 42.5 & 26 \\
\hline \multicolumn{16}{|l|}{ Blood pressure $(\mathrm{mm} \mathrm{Hg})$ : } \\
\hline Diastolic & 395 & 80 & 10 & 84 & 80 & 10 & 101 & 90 & 10 & 105 & 90 & 10 & 93 & 90 & 20 \\
\hline Systolic & 395 & 130 & 30 & 84 & 140 & 30 & 101 & 140 & 20 & 105 & 140 & 10 & 93 & 140 & 20 \\
\hline \multicolumn{16}{|l|}{ Medication (days in past year): } \\
\hline Analgesics & 382 & 3 & 15 & 82 & 7 & 20 & 95 & 8 & 26 & 95 & 3 & 12 & 78 & 6 & 27 \\
\hline Heart medication & 382 & 0 & 0 & 82 & 0 & 0 & 95 & 0 & 0 & 95 & 0 & 0 & 78 & 0 & 0 \\
\hline $\begin{array}{l}\text { Duration of residence in } \\
\text { contaminated estate }(y) \text { : }\end{array}$ & 382 & 8.5 & 24 & 82 & 14 & 36 & 95 & 20 & 36 & 95 & 23 & 28 & 78 & 30 & 22 \\
\hline Cadmium in urine $/ 24 \mathrm{~h}(\mu \mathrm{g})$ & 434 & 0.32 & 0.33 & 92 & 0.41 & 0.49 & 104 & 0.45 & 0.40 & 107 & 0.44 & 0.56 & 94 & 0.53 & 0.47 \\
\hline Cadmium in blood $(\mu \mathrm{g} / \mathrm{l})$ & 429 & 0.7 & 0.8 & 92 & 0.7 & 0.8 & 104 & 0.6 & 0.7 & 106 & 0.7 & 0.8 & 93 & 0.7 & 0.8 \\
\hline Urine volume collected $(\mathrm{ml})$ & 434 & 1500 & 900 & 92 & 1175 & 695 & 104 & 1350 & 800 & 107 & 1250 & 750 & 94 & 1475 & 700 \\
\hline Creatinine in serum $(\mathrm{mg} / \mathrm{dl})$ & 429 & 0.8 & 0.2 & 92 & 0.9 & 0.2 & 103 & 0.9 & 0.2 & 107 & 0.9 & 0.1 & 94 & 1.0 & 0.2 \\
\hline Creatinine in urine $(\mathrm{g} / 24 \mathrm{~h})$ & 396 & 1.2 & 0.6 & 81 & 1.3 & 0.7 & 99 & 1.4 & 0.7 & 101 & 1.4 & 0.6 & 89 & 1.4 & 0.8 \\
\hline $\begin{array}{l}\text { Estimated creatinine clearance } \\
(\mathrm{ml} / \mathrm{min})\end{array}$ & 395 & 102 & 38 & 80 & 103 & 28 & 95 & 92 & 33 & 97 & 98 & 45 & 80 & 94 & 43 \\
\hline
\end{tabular}

$\mathrm{IQR}=$ interquartile range. 
Table 5 Spearman correlation between predictors and the urinary excretion of a-1-microglobulin and cadmium

\begin{tabular}{|c|c|c|c|c|c|}
\hline \multirow[b]{2}{*}{ Predictors } & \multirow[b]{2}{*}{$n$} & \multicolumn{2}{|c|}{ a-1-microglobulin/24 h } & \multicolumn{2}{|c|}{ Cadmium in urine $/ 24 \mathrm{~h}$} \\
\hline & & $\begin{array}{l}\text { Correlation } \\
\text { coefficient }\end{array}$ & $p$ Value & $\begin{array}{l}\text { Correlation } \\
\text { coefficient }\end{array}$ & $p$ Value \\
\hline Cadmium excretion in urine $/ 24 \mathrm{~h}$ & 831 & 0.19 & 0.0001 & - & - \\
\hline Age & 831 & 0.24 & 0.0001 & 0.35 & 0.0001 \\
\hline Pack-years of cigarettes & 732 & 0.16 & 0.0001 & 0.21 & 0.0001 \\
\hline Socioeconomic status & 731 & -0.007 & 0.8502 & -0.07 & 0.0540 \\
\hline Blood pressure, diastolic & 778 & 0.15 & 0.0001 & 0.15 & 0.0001 \\
\hline Blood pressure, systolic & 778 & 0.13 & 0.0002 & 0.17 & 0.0001 \\
\hline Cadmium concentration in blood & 824 & -0.01 & 0.7695 & 0.13 & 0.0001 \\
\hline Residence on contaminated soil & 732 & 0.29 & 0.0001 & 0.13 & 0.0006 \\
\hline Analgesics & 732 & 0.03 & 0.3042 & 0.02 & 0.6354 \\
\hline Heart medication & 732 & 0.12 & 0.0008 & 0.01 & 0.7343 \\
\hline Occupational exposure & 732 & 0.21 & 0.0001 & 0.12 & 0.0014 \\
\hline Serum creatinine & 825 & 0.30 & 0.0001 & 0.13 & 0.0003 \\
\hline Creatinine in urine & 766 & 0.18 & 0.0001 & 0.11 & 0.0015 \\
\hline Estimated creatinine clearance & 747 & -0.12 & 0.0006 & -0.07 & 0.0537 \\
\hline
\end{tabular}

Table 6 Association between a-1-microglobulin and predictors

\begin{tabular}{|c|c|c|}
\hline Predictor & $\begin{array}{l}<50 \text { y }(n=431) \\
\text { OR }(95 \% C I)\end{array}$ & $\begin{array}{l}\text { Complete sample }(n=732) \\
\text { OR }(95 \% C I)\end{array}$ \\
\hline Cadmium excretion $/ 24 \mathrm{~h}(\mu \mathrm{g})$ & $2.26(1.38$ to 3.70$)$ & $1.30 \quad(0.96$ to 1.77$)$ \\
\hline Sex $($ male $=1$, female $=0)$ & $1.76 \quad(1.13$ to 2.73$)$ & $2.14 \quad(1.56$ to 2.94$)$ \\
\hline Age-group 1: >30-40 y & $1.71^{\star}(1.02$ to 2.86$)$ & $1.84^{\star}(1.13$ to 3.00$)$ \\
\hline Age-group 2: $>40-50 \mathrm{y}$ & 1.42 (0.83 to 2.42$)$ & 1.59 (0.95 to 2.66$)$ \\
\hline Age-group 3: $>50-60$ y & - & $2.23(1.30$ to 3.84$)$ \\
\hline Age-group 4: >60 y & - & 2.55 (1.47 to 4.42$)$ \\
\hline Occupational exposure (yes/no) & $1.71 \quad(1.03$ to 2.83$)$ & $1.28(0.90$ to 1.81$)$ \\
\hline Estimated creatinine clearance & $1.001(0.996$ to 1.006$)$ & $0.999(0.994$ to 1.004$)$ \\
\hline Duration of soil exposure (y) & $1.03(1.01$ to 1.04$)$ & $1.03(1.02$ to 1.04$)$ \\
\hline Joint significance of explanatory variables & $\chi^{2} 61.7, \mathrm{df} 7, \mathrm{p}=0.0001$ & $\chi^{2} 108.2$, df $9, p=0.0001$ \\
\hline
\end{tabular}

${ }^{\star}$ Odds ratio calculated with age group up to 30 years as reference.

$\mathrm{df}=$ degrees of freedom.

logistic regression for the total sample gave significant results only for age, sex, and the duration of living on contaminated soil. The OR for age categories showed a significant increase compared with those aged $\leqslant 30$ for age groups $30-40,41-60$, and $\geqslant 60$. Males showed a $2.14-$ fold (95\% CI 1.56 to 2.94) higher odds compared with females. The OR for the duration of soil exposure was 1.03 / year (95\% CI 1.02 to 1.04 ) resulting in an OR of 1.81 for 20 years of exposure.

The final model for the age group $\leqslant 50$ years differed from that for the total sample; it also included the cadmium excretion / $24 \mathrm{~h}$ with an OR of 2.26. We therefore had to conclude that the excretion of $\alpha-1$-microglobulin was only explained by the cadmium body burden in the younger age group.

\section{Discussion}

The distribution of the urinary $\alpha-1$ microglobulin excretion was bimodal both in the exposed and in the control groups. Analyses took this into consideration with nonparametric statistical methods and ordinal logistic regression. This had been previously applied by Jung et $a l,{ }^{15}$ who studied the spot urine of 73 healthy people, 36 environmentally exposed people, and 62 occupationally exposed people. They reported Spearman's correlations between the urinary cadmium excretion and $\alpha-1$-microglobulin, $\mathrm{N}$-acetyl- $\beta$ glucosaminidase (NAG), retinol binding protein, and other indicators of tubular and glomerular dysfunction.

The stratified analysis of the excretion of $\alpha-1$-microglobulin with various predictors identified the urinary cadmium excretion, age, sex, smoking history, occupational exposure, duration of soil exposure, and blood pressure as relevant determinants of $\alpha-1$-microglobulin. With regard to the association of $\alpha-1$ microglobulin with age, sex, and occupational exposure, results were consistent with findings in the literature. ${ }^{1625-28}$ The other predictors had to the best of our knowledge not been previously studied. The correlation of $\alpha-1-$ microglobulin with the urinary cadmium excretion of 0.19 was in agreement with the study by Jung et al. ${ }^{15}$

Although several predictors reached significance in the bivariate association, the final multivariate model consisted only of age group, sex, and the duration of soil exposure if all people with a complete set of data were included. Males showed a twofold odds compared with females for having values of $\alpha$-1-microglobulin above any set cut off point if the other explanatory variables were kept constant. The OR for duration of soil exposure was low. Nevertheless, 20 years of soil exposure resulted in an OR of 1.81. For age a gradient of ORs was found with higher ORs in older age groups. It could, therefore, be concluded that age and soil exposure represented the clinically relevant determinants of $\alpha$-1-microglobulin in the present sample. The glomerular filtration rate estimated as creatinine clearance did not play an important part in explaining the excretion of $\alpha$-1-microglobulin.

For the age group $\leqslant 50$ years the resulting final model differed from that for the whole sample. Although for the whole sample the urinary cadmium excretion was not significantly associated with the excretion of $\alpha-1$ microglobulin in the age group up to 50 years, a urinary cadmium excretion of $1 \mu \mathrm{g} / 24 \mathrm{~h}$ resulted in an OR of 2.28 for having $\alpha-1-$ microglobulin values above any set boundary. This is a very interesting observation because people $>50$ years of age are considered to be a high risk group for renal dysfunction induced by cadmium. Similarly, occupational exposure had a significant and stronger effect for the younger age group. The influence of duration of living on contaminated soil showed an effect of similar magnitude and significance in both groups. The OR for sex was considerably higher for the whole sample than for the age group $<50$ years thus indicating its stronger effect in the older age groups.

The data presented here provide evidence that the urinary excretion of $\alpha-1$-microglobulin is associated with the urinary cadmium excretion only in people of $<50$ years of age, with age, sex, and occupational and residential exposure being other relevant predictors. As the urinary cadmium excretion was controlled in the model, the variable "duration of soil exposure" could be interpreted as a surrogate for exposure to one or more of the soil contaminants other than cadmium. Contaminants included lead, arsenic, mercury, and dioxins / furans. Recent studies looking at the excretion of $\alpha$-1-microglobulin in workers and in children exposed to lead, ${ }^{29}{ }^{31}$ concluded that lead workers with blood lead concentrations $>20.0 \mu \mathrm{g} / \mathrm{dl}$ showed renal dysfunction 
represented by a significant increase of the urinary $\alpha-1$-microglobulin excretion. ${ }^{29}$ However, other studies found no association between the excretion of $\beta$-2-microglobulin or $\alpha-1$ microglobulin and exposure to lead.$^{29}$

The evidence presented here points towards a high sensitivity of $\alpha-1$-microglobulin to indicate renal tubular damage specific to cadmium. However, chronic cadmium exposure as expressed by the urinary cadmium excretion only partly explained the $\alpha-1$-microglobulin excretion in the age group $\leqslant 50$ years of age and was non-significant if people of all ages were included. This could be biologically plausible if cadmium body depots in a proportion of older people were emptied due to manifest renal damage..$^{513}$ The total sample might include a relevant proportion of people in whom the cadmium excretion is no longer correlated with cadmium body burden. Further studies about the time and exposure pattern of changes of the urinary excretion of cadmium and $\alpha-1$-microglobulin, as well as blood lead concentrations, will be needed to fully understand how the renal tubules respond to different influencing factors by increasing the excretion of $\alpha-1$ microglobulin.

\section{Conclusion}

$\alpha-1-$ Microglobulin is a suitable marker for early tubular changes only for people $\leqslant 50$ years. The excretion of $\alpha-1$-microglobulin increases with increasing body burden of cadmium. However, in epidemiological studies urinary $\alpha-1-$ microglobulin excretion is not a suitable surrogate for renal dysfunction induced by cadmium as other environmental and occupational exposures influence the excretion. Yet, if the exact composition of the underlying exposure is not of prime interest, testing for $\alpha-1$-microglobulin may provide a valuable measure of early tubular renal changes. Alternatively, the combination of $\alpha-1$-microglobulin with other biological markers such as retinol binding protein should be considered in future epidemiological research.

Results in this paper were derived from a dissertation which was part of an MS Scotland in 1993. Raymond Agius, Rob Elton, and Celia McIntyre of the Department of Public Health Sciences, Edinburgh have supported the data analysis with epidemiological and statistical advice. Financial support for the MSc course was granted partly by the Grman A ror the granted partly by the German Academic Exchange Service (DAAD) and by the World Health Organisation (WHO). We thank $M$ Dulon of NORDIG for preparing the data set and comments by Dr T Kiellstroems (GEENET, WHO, Geneva) on the MSc dissertation. Comments of Professor Raj Bhopal and Denise Howel (Department of Epidemiology and Public Health, Newcastle) on previous drafts of this paper are gratefully acknowledged. The data set is derived from an epidemiologica study conducted by the NORDIG Institute for Health Research and Prevention Hamburg funded by the Local Health Authority, Hamburg, Germany.

1 Kjellstroem T, Ervin PE, Rahnster B. Dose-response relationship of cadmium induced tubular proteinuria. Environ Res 1977; 13:303-17.

2 Maack T, Johnson V, Kau ST, et al. Renal filtration, transport and metabolism of low molecular weight proteins: a review. Kidney Int 1979;16:251-70.
3 Friberg L. Cadmium and the kidney. Environ Health Perspect 1984;554:1-11.

4 Lauwerys RR, Bernard A, Roels HA, et al. Characterisation of cadmium proteinuria in man and rat. Environ Health Perspect 1984;54:147-52.

5 Buchet JP, Lauwerys R, Roels H, et al. Renal effects of cadmium body burden in the general population. Lancet 1990; 336:699-702.

6 Piscator M. Early detection of tubular dysfunction. Kidney Int 1991;40(suppl 34):15-17.

7 Mutti A. Detection of renal diseases in humans: developing markers and methods. Toxicol Lett 1989;46:177-91.

8 Liedvogel B. Alpha-1-mikroglobulin Klinische und wissenschaftliche Daten/Indikationen. Extracta Diagnostica 1989; 3:236-40.

9 Herber RFM, VerschooR MA, Wibowo AAE. Review of the kinetics and kidney effects of cadmium-recent epidemiological studies. In: Stoeppler M, Piscator M, eds. Cadmium. 3rd IUPAC cadmium workshop. Juelich, FRG: Springer, 3rd IUPAC cadmium workshop. Juelich, FRG:

10 Roels H, Bernard AM, Cardenas A, et al. Markers of early renal changes induced by industrial pollutants III Application to workers exposed to cadmium. $\mathrm{Br} F$ Ind $\mathrm{Med}$ 1993;50:37-48.

11 Dubach UC, LE Hir M, Gandhi R. Use of urinary enzymes as markers of nephrotoxicity. Toxicol Lett 1989;46:193-6.

12 Shiroishi K, Kjellstroem T, Kubota K, et al. Urinary analysis for detection of cadmium induced renal changes with special reference to $\beta-2-$ microglobulin. Environ Res 1977;13: $407-24$

13 Nogawa K. Biological indicators of cadmium nephrotoxicity in persons with low level cadmium exposure. Environ Health Perspect 1984;54:163-169.

14 Ewers U, Brockhaus A, Dolgner R, et al. Environmental exposure to cadmium and renal function of elderly women living in cadmium polluted areas of the Federal Republic of Germany. Int Arch Occup Environ Health 1985;55:217-39.

15 Jung K, Pergande M, Graubaum HJ, et al. Urinary proteins and enzymes as early indicators of renal dysfunction in chronic exposure to cadmium. Clinical Chemistry 1993;39: 757-65.

16 Itoh Y, Enomoto T, Kawai T. Alpha-1-microglobulin in cadmium poisoning. Nephron 1983;35:211-12.

17 Kido T, Honda R, Yamada Y, et al. Alpha-1-microglobulin in urine for the early detection of renal tubular dysfunction caused by exposure to cadmium. Toxicol Lett 1985;24:195201.

18 Tokyama C, Kobayashi E, Saito $\mathrm{H}$, et al. Urinary alpha-1-microglobulin as an indicator protein of renal tubular dysfunction caused by environmental cadmium exposure. F Appl Toxicol 1986;6:171-8.

$19 \mathrm{Yu} \mathrm{H}$, Yanagisawa Y, Forbes MA, et al. Alpha-1microglobulin: an indicator for renal tubular dysfunction. $\mathcal{F}$ Clin Pathol 1983;36:253-9.

20 Donaldson MDC, Chambers RE, Woolridge MW, et al. Stability of $\alpha$-1-microglobulin, $\beta-2$-microglobulin and retinolbinding-protein in urine. Clin Chim Acta 1989;179:73-8.

21 Hamburg Health Authority, ed. Gesundheitsbehörde der Freien und Hansestadt Hamburg. Epidemiologisches Untersuchungsprogramm Billesiedlung. Frankfurt: Peter Lang, 1997

22 LC-Partigen Immunodiffusion plates for the quantitative determination of proteins in low concentration ranges. Marburg: Behring, 1991.

23 SAS/STAT. The logistic procedure chap 27 in: User's guide version 6, 4th ed 1990. Vol 2. Cary, NC: SAS 1071-126.

24 Armstrong BG, Sloan M. Ordinal regression of epidemiologic data. Am ₹ Epidemiol 1989;129:191-204.

25 Kusano E, Suzuki M, Asano Y, et al. Human a-1microglobulin and its relationship to renal function. Nephron 1985;41:320-4.

26 Itoh Y, Kawai T. Sex differences in urinary $\alpha-1$ microglobulin values in normal individuals. Nephron 1991; 57:121-2.

27 Jung K, Pergande M, Schreiber G, et al. Reference intervals for $\alpha$-1-microglobulin in urine. Clinica Chimica Acta 1992; 206:245-7.

28 Kjellstroem T, Elinder CG, Friberg L. Conceptual problems in establishing the critical concentration of cadmium in human kidney cortex. Environ Res 1984;33:284-95.

29 Endo G, Konishi Y, Kiyoto A, et al. Urinary $\alpha-1-$ microglobulin in lead workers. Bull Environ Contam Toxicol 1993;50:744-9.

30 Cardenas A, Roels H, Bernard AM, et al. Markers of early renal changes induced by industrial pollutants II. Application to workers exposed to lead. Br f Ind Med 1993;50:2836.

31 Verberk MM, Willems TEP, Verplanke AJW, et al. Environmental lead and renal effects in children. Arch Environ Health 1996;51:83-7. 